\title{
JEKK
}

\section{Persepsi dan Partisipasi Wisatawan terhadap Sampah di Pantai Pasir Padi Pulau Bangka}

\author{
Eka Sari", Fika Dewi Pratiwi** \\ *Jurusan Biologi Universitas Bangka Belitung, ${ }^{* *}$ Jurusan Manajemen Sumberdaya Perairan Universitas \\ Bangka Belitung
}

\begin{abstract}
Background: Trash could affects the environment sustainability. The amount of rubbish in Pasir Padi Beach is about the assessment of public awareness, understanding of the assessment and participation of tourists visiting the beach about rubbish. Therefore, this study discusses the perception and participation of tourists related to trash cans in Pasir Padi Beach.

Methods: The instrument used consisted of questionnaires with a Likert scale. The validity and reliability testing of each instrument uses the product valuation and Cronbach's alpha method, respectively and both were analyzed by Microsoft Excel.

Result: The value of $r$ count $(1,688-14,099)>r$ table value $(1,661)$ on the validity test, while the Cronbach's Alpha value on the reliability test (perception $=0,888$; participation $=0,937$ ) $>0,66$. The percentage who answered quite agree until agree on the instrument of perception and participation were $63 \%-100 \%$ and $55 \%-78 \%$, respectively

Conclusion : Related to the perception of Coastal waste as follows: the most distribution in Coastal and Coastal settlements, the largest source of food stalls, has no place to move garbage around the coast and there are no definite regulations which are the main causative factors, the main impact of waste is human health. The most important participation of the community in the action of reducing Coastal waste in Pasir Padi Beach is disposing of garbage in existing rubbish bins. All groups and levels of society have responsibility for beach cleanliness. In realizing the cleanliness of the Pangkal Pinang Coastal City, Bangka Island.
\end{abstract}

Keywords: Bangka; Pasir Padi Beach; participation; perception; rubbish

*Penulis korespondensi, ekasari090@gmail.com 


\section{Pendahuluan}

Sektor wisata bahari merupakan salah satu sektor unggulan di berbagai negara, termasuk Indonesia karena pemasukannya dapat meningkatkan pertumbuhan ekonomi dan sebagai sumber devisa negara. ${ }^{1}$ Salah satu masalah kompleks wisata bahari yang sedang berkembang pesat di suatu wilayah adalah sampah yang berasal dari aktivitas wisatawan yang mengunjungi lokasi wisata. Sampah tersebut dapat menjadi ancaman bagi keberlanjutan wisata bahari sampai dengan kelestarian hidup lingkungan perairan. Permasalahan tersebut juga terjadi pada salah satu lokasi wisata bahari yang terletak di Provinsi Kepulauan Bangka Belitung yaitu pantai Pasir Padi Kota Pangkalpinang di Pulau Bangka.

Pantai Pasir Padi banyak dikunjungi wisatawan, dengan panjang pantai kurang lebih $2 \mathrm{~km}$ dan memiliki hamparan pasir putih serta daya tarik pemandangan laut yang disukai wisatawan. Namun, kehadiran para wisatawan di Pantai Pasir Padi seringkali meninggalkan sampah di pantai secara sengaja atau tidak sengaja di pantai. Oleh karenanya monitoring sampah di pantai sebagai akibat wisata bahari adalah penting dilakukan karena hal tersebut dapat mengurangi risiko ancaman ekologi, serta kelestarian lingkungan akibat aktivitas manusia. $^{2}$

Timbunan sampah di Provinsi Kepulauan Bangka Belitung mencapai 1.114,07 ton/hari atau 406.634,38 ton/tahun. Dari total sampah tersebut, yang hanya dapat dikelola di Tempat Pembuangan Akhir (TPA) sebesar 249.000 ton/tahun. Kota Pangkalpinang merupakan daerah penyumbang sampah terbesar. Pengelolaan sampah di provinsi ini umumnya masih menggunakan paradigma lama yaitu dengan cara mengumpulkan, mengangkut dan membuang. ${ }^{3}$

Tingginya sampah di Kota Pangkalpinang, khususnya di Pantai Pasir Padi, kemungkinan mengindikasikan bahwa masih rendahnya kesadaran dan pemahaman masyarakat, sehingga perlu adanya kajian mengenai persepsi dan partisipasi wisatawan yang berkunjung ke pantai mengenai sampah. Manusia akan terus menerus mengadakan hubungan dengan lingkungannya melalui persepsi. Persepsi tersebut dapat mempengaruhi bentuk tingkah laku individu dalam kehidupan sehari-harinya. ${ }^{4}$ Begitu juga dengan partisipasi yang menentukan arah dan strategi dalam kebijakan kegiatan, memikul beban dalam pelaksanaan kegiatan, dan memetik hasil dan manfaat kegiatan secara merata. Persepsi dan partisipasi masyarakat mempunyai peran penting dalam pengambilan kebijakan dalam penentuan cara yang efektif dalam pengelolaan sampah, khususnya sampah laut sehingga berdampak pada kebersihan dan kelestarian lingkungan perairan. Oleh karena itu, penelitian ini bertujuan mengungkapkan persepsi dan partisipasi wisatawan terkait sampah pesisir di Pantai Pasir Padi. ${ }^{2,4}$

\section{Metode}

\section{Kuesioner Persepsi dan Partisipasi Wisatawan}

Penelitian dilaksanakan pada bulan Juli tahun 2019 di Pantai Pasir Padi, Kota Pangkalpinang, Pulau Bangka, Provinsi Kepulauan Bangka Belitung. Pengambilan data persepsi dan partisipasi masyarakat terhadap sampah di pantai akibat aktivitas wisata bahari dilakukan dengan menggunakan perangkat kuesioner telah diuji tingkat validitas dan reliabilitasnya. Metode pemilihan wisatawan adalah purposive sampling. Responden yang dipilih merupakan wisatawan yang mengunjungi pantai Pasir Padi sejumlah 100 orang. Kuesioner tertutup digunakan untuk mengetahui persepsi wisatawan terhadap aktivitas wisata bahari dan sampah di pantai dan tingkat partisipasi masyarakat dalam menjaga estetika dan kelestarian lingkungan hidup dalam hal ini wisata bahari. Kuesioner bersifat kualitatif selanjutnya akan dikuantitatifkan dengan menggunakan skala Likert dengan criteria sebagai berikut: Skor $5=$ Sangat Setuju; Skor $4=$ Setuju; Skor 3= Cukup Setuju; Skor 2= kurang Setuju; $1=$ Tidak Setuju ; $0=$ tidak ada jawaban. 


\section{Analisis Instrumen Penelitian}

Analisis instrument penelitian yang dimaksud adalah uji validitas dan reliabilitas kuesioner yaitu:

\section{Uji Validitas}

Metode yang digunakan untuk menguji validitas instrumen adalah metode korelasi produk momen (moment product correlation, Pearson correlation). Instrumen penelitian dikatakan valid apabila nilai koefisien product moment (r) lebih dari $\mathrm{r}$ table $(\alpha ; \mathrm{n}-2)$ atau nilainya telah memenuhi kriteria sig $\leq \alpha$. Simbol a menunjukkan taraf signifikansi, sedangkan $\mathrm{n}$ berarti jumlah data penelitian yang diobservasi. ${ }^{5}$

\section{Uji Reliabilitas}

Uji reabilitas menggunakan menggunakan metode Cronbach's alpha. Kueisoner dikatakan reliable apabila jawaban responden adalah konsisten atau stabil selama penelitian. Skala Likert digunakan untuk menilai jawaban responden penelitian. Instrumen penelitian dinyatakan reliabel apabila nilainya memenuhi persyaratan reliabilitas instrumen $\left(\mathrm{r}_{11}\right)>\mathrm{r}$ tabel $(\alpha ; \mathrm{n}-2)$. Nilai $\alpha$ merupakan taraf signifikansi dan $n$ berarti jumlah data penelitian yang diobservasi. $^{6}$

\section{Hasil Penelitian}

Karakteristik wisatawan Pantai Pasir Padi mempunyai rasio yang hampir sama antara perempuan dan laki-laki dengan variasi umur dari 10 tahun sampai dengan 60 tahun. Sebagian besar wisatawan berasal dari Kota Pangkalpinang, karena lokasi Pantai Pasir Padi memang tidak begitu jauh dari ibu kota Provinsi Kepulauan Bangka Belitung ini (yaitu kurang lebih waktu tempuh perjalanan selama 30 menit). Semua wisatawan rata-rata mempunyai pendidikan dari sekolah dasar sampai dengan perguruan tinggi dengan latar belakang pekerjaan yang beraneka ragam, dari ibu rumah tangga, pegawai swasta, dan lain sebagainya. Cara sebagian besar wisatawan memperoleh informasi tentang pantai ini, yakni melalui Informasi lisan baik dari keluarga, saudara, teman, sekolah, maupun relasi. Tujuan utama wisatawan mengunjungi Pantai Pasir Padi terutama pada hari libur bersama anggota keluarga (2 sampai dengan 10 orang) yaitu rekreasi/liburan dengan menggunakan kendaraan pribadi (motor atau mobil). Ada berbagai macam cara mereka untuk memperoleh makanan ketika berkunjung, yaitu: membawa bekal dari rumah, makan di warung kecil, membeli makanan dari pedagang keliling, makan di restaurant, tergantung keadaan (Tabel 1). Nilai $r$ hitung pada uji validitas berkisar dari 1,688 - 14,099 sementara nilai $r$ tabel adalah 1,661 (Tabel 2). Nilai Cronbach's Alpha pada uji reliabilitas untuk instrumen persepsi adalah 0,888 sementara nilai instrumen partisipasi adalah 0,937 (Tabel 3).

Tabel 1. Hasil karakteristik wisatawan Pantai Pasir Padi

\begin{tabular}{|c|c|c|}
\hline No & $\begin{array}{l}\text { Karakteristik } \\
\text { Wisatawan Pantai }\end{array}$ & Hasil \\
\hline 1 & Jenis Kelamin & Perempuan (59\%), laki-laki (41\%) \\
\hline 2 & Umur & $\begin{array}{l}>20 \text { tahun s.d }<30 \text { tahun }(38 \%),>30 \text { tahun s.d }<40 \text { tahun }(26 \%),>40 \\
\text { tahun s.d }<50 \text { tahun }(17 \%),>50 \text { tahun s.d }<60 \text { tahun }(10 \%),>10 \text { tahun } \\
\text { s.d }<20 \text { tahun }(9 \%)\end{array}$ \\
\hline 3 & Asal & $\begin{array}{l}\text { Kota Pangkalpinang }(70 \%) \text {, LuarPulau Bangka }(15 \%) \text {, Kabupaten } \\
\text { Bangka }(7 \%) \text {, Kabupaten Bangka Tengah }(5 \%) \text {, Kabupaten Bangka } \\
\text { Selatan }(2 \%) \text {, Kabupaten Bangka Barat }(1 \%)\end{array}$ \\
\hline 4 & Pendidikan & $\begin{array}{l}\text { SMA/Sederajat }(55 \%) \text {, Sarjana }(22 \%) \text {, SMP/Sederajat (12\%), Diploma } \\
(5 \%), \text { SD/Sederajat }(5 \%) \text {, tidak tamat SD }(1 \%)\end{array}$ \\
\hline 5 & Pekerjaan & $\begin{array}{l}\text { Ibu Rumah Tangga (20\%), Pegawai Swasta }(20 \%) \text {, Wirausaha }(19 \%) \text {, } \\
\text { Pelajar }(11 \%) \text {, Mahasiswa/wi }(8 \%) \text {, Buruh Harian Lepas }(7 \%) \text {, }\end{array}$ \\
\hline
\end{tabular}




\begin{tabular}{|c|c|c|}
\hline No & $\begin{array}{l}\text { Karakteristik } \\
\text { Wisatawan Pantai }\end{array}$ & Hasil \\
\hline & & $\begin{array}{l}\text { Pedagang (5\%), BUMN (3\%), PNS (3\%), Petani (2\%), Guru (1\%), } \\
\text { TNI/POLRI/ABRI (1\%) }\end{array}$ \\
\hline 6 & $\begin{array}{l}\text { Sumber informasi } \\
\text { Pantai Pasir Padi }\end{array}$ & $\begin{array}{l}\text { Informasi lisan (keluarga, saudara, teman, sekolah, relasi) [86\%], media } \\
\text { sosial (facebook, instagram, twitter) [7\%], dari media cetak (koran, } \\
\text { majalah, brosur, leaflet, poster) [4\%], media elektronik (televisi, radio } \\
\text { dan internet) [3\%] }\end{array}$ \\
\hline 7 & $\begin{array}{l}\text { Tujuan kunjungan ke } \\
\text { Pantai Pasir Padi }\end{array}$ & Rekreasi/liburan (96\%), Berdagang/Berwirausaha (3\%), Olahraga (1\%) \\
\hline 8 & $\begin{array}{l}\text { Waktu kunjungan ke } \\
\text { Pantai Pasir Padi }\end{array}$ & $\begin{array}{l}\text { Hari libur }(63 \%) \text {, akhir pekan }(32 \%) \text {, setiap hari }(2 \%) \text {, seperlunya } \\
\text { dan/atau tidak tentu }(2 \%) \text {, hari kerja }(1 \%)\end{array}$ \\
\hline 9 & $\begin{array}{l}\text { Yang diajak saat } \\
\text { kunjungan ke Pantai } \\
\text { Pasir Padi }\end{array}$ & $\begin{array}{l}\text { Keluarga ( } 2 \text { s.d } 12 \text { orang) [69\%], teman-teman ( } 2 \text { s.d } 30 \text { orang) [14\%], } \\
\text { teman dekat }(3 \%) \text {, kelompok wisata }(1 \%)\end{array}$ \\
\hline 10 & $\begin{array}{l}\text { Transportasi saat } \\
\text { kunjungan ke Pantai } \\
\text { Pasir Padi }\end{array}$ & $\begin{array}{l}\text { Kendaraan Pribadi (motor dan/atau mobil) [98\%], bus (1\%), jalan kaki } \\
(1 \%)\end{array}$ \\
\hline 11 & $\begin{array}{l}\text { Cara memperoleh } \\
\text { makanan saat } \\
\text { kunjungan ke Pantai } \\
\text { Pasir Padi }\end{array}$ & $\begin{array}{l}\text { Membawa bekal dari rumah (53\%), makan di warung kecil }(23 \%) \text {, beli } \\
\text { makanan dari pedagang keliling }(17 \%) \text {, makan di restaurant }(6 \%) \text {, } \\
\text { tergantung keadaan }(1 \%)\end{array}$ \\
\hline 12 & $\begin{array}{l}\text { Cara wisatawan } \\
\text { membuang sampah } \\
\text { di Pantai Pasir Padi }\end{array}$ & $\begin{array}{l}\text { Di tempat sampah }(78 \%) \text {, di simpan di tas dan dibawa pulang }(13 \%) \text {, di } \\
\text { sembarang tempat }(5 \%) \text {, di tempat penyedia makanan }(3 \%) \text {, di jalan } \\
(1 \%)\end{array}$ \\
\hline
\end{tabular}

Tabel 2. Hasi uji validitas Instrumen Persepsi dan Partisipasi Wisatawan Pantai Pasir Padi, Bangka menggunakan metode korelasi produk momen

\begin{tabular}{cccccccc}
\hline \multicolumn{3}{c}{ Uji Validasi Persepsi } & & \multicolumn{3}{c}{ Uji Validasi Partisipasi } \\
$\begin{array}{c}\text { No Butir } \\
\text { Soal }\end{array}$ & $\begin{array}{c}\text { Koefisien } \\
\text { validitas } \\
\text { instrumen } \\
\text { hitung) }\end{array}$ & $\begin{array}{c}\text { r } \mathbf{r a b e l} \\
\text { Pearson }\end{array}$ & Kriteria & $\begin{array}{c}\text { No Butir } \\
\text { Soal }\end{array}$ & $\begin{array}{c}\text { Koefisien } \\
\text { validitas } \\
\text { instrumen } \\
\text { (r hitung) }\end{array}$ & $\begin{array}{c}\mathbf{r}_{\text {tabel }} \\
\text { Pearson }\end{array}$ & Kriteria \\
\hline S1 & 3,422 & 1,661 & Valid & T1 & 6,607 & 1,661 & Valid \\
S2 & 2,184 & 1,661 & Valid & T2 & 4,218 & 1,661 & Valid \\
S3 & 4,022 & 1,661 & Valid & T3 & 5,838 & 1,661 & Valid \\
S4 & 5,120 & 1,661 & Valid & T4 & 5,408 & 1,661 & Valid \\
S5 & 5,763 & 1,661 & Valid & T5 & 6,951 & 1,661 & Valid \\
S6 & 5,911 & 1,661 & Valid & T6 & 7,541 & 1,661 & Valid \\
S7 & 4,586 & 1,661 & Valid & T7 & 6,112 & 1,661 & Valid \\
S8 & 8,300 & 1,661 & Valid & T8 & 8,395 & 1,661 & Valid \\
S9 & 5,095 & 1,661 & Valid & T9 & 14,099 & 1,661 & Valid \\
S10 & 6,379 & 1,661 & Valid & T10 & 12,667 & 1,661 & Valid \\
S11 & 6,139 & 1,661 & Valid & T11 & 9,736 & 1,661 & Valid \\
S12 & 8,278 & 1,661 & Valid & T12 & 12,048 & 1,661 & Valid \\
S13 & 6,723 & 1,661 & Valid & T13 & 12,683 & 1,661 & Valid \\
S14 & 8,961 & 1,661 & Valid & T14 & 9,509 & 1,661 & Valid \\
S15 & 7,191 & 1,661 & Valid & T15 & 12,104 & 1,661 & Valid \\
\hline
\end{tabular}




\begin{tabular}{cccccccc}
\hline Uji Validasi Persepsi & & \multicolumn{3}{c}{ Uji Validasi Partisipasi } \\
\hline $\begin{array}{c}\text { No Butir } \\
\text { Soal }\end{array}$ & $\begin{array}{c}\text { Koefisien } \\
\text { validitas } \\
\text { instrumen } \\
\text { hitung) }\end{array}$ & $\begin{array}{c}\mathbf{r}_{\text {tabel }} \\
\text { Pearson }\end{array}$ & Kriteria & $\begin{array}{c}\text { No Butir } \\
\text { Soal }\end{array}$ & $\begin{array}{c}\text { Koefisien } \\
\text { validitas } \\
\text { instrumen } \\
\text { (r hitung) }\end{array}$ & $\begin{array}{c}\mathbf{r}_{\text {tabel }} \\
\text { Pearson }\end{array}$ & Kriteria \\
\hline S16 & 6,748 & 1,661 & Valid & T16 & 13,387 & 1,661 & Valid \\
S17 & 7,556 & 1,661 & Valid & T17 & 9,863 & 1,661 & Valid \\
S18 & 6,058 & 1,661 & Valid & T18 & 12,356 & 1,661 & Valid \\
S19 & 6,141 & 1,661 & Valid & T19 & 12,591 & 1,661 & Valid \\
S20 & 6,257 & 1,661 & Valid & & & & \\
S21 & 5,540 & 1,661 & Valid & & & & \\
S22 & 5,305 & 1,661 & Valid & & & & \\
S23 & 6,884 & 1,661 & Valid & & & & \\
S24 & 6,565 & 1,661 & Valid & & & & \\
S25 & 4,383 & 1,661 & Valid & & & & \\
S26 & 1,688 & 1,661 & Valid & & & & \\
S27 & 7,515 & 1,661 & Valid & & & & \\
S28 & 5,661 & 1,661 & Valid & & & & \\
S29 & 5,066 & 1,661 & Valid & & & & \\
\hline
\end{tabular}

Tabel 3. Hasi uji reabilitas Instrumen Persepsi dan Partisipasi Wisatawan Pantai Pasir Padi, Bangka menggunakan Cronbach Alpha

\begin{tabular}{llll}
\hline No & Variabel & ralpha & Kriteria \\
\hline 1 & Persepsi wisatawan Pantai Pasir Padi & 0,888 & Reliabel \\
2 & Partisipasi wisatawan Pantai Pasir Padi & 0,937 & Reliabel \\
\hline
\end{tabular}

Wisatawan Pantai Pasir Padi beranggapan bahwa lokasi dengan distribusi sampah terbanyak ada di pesisir pantai dan pemukiman pesisir pantai, sementara tidak banyak ditemukan di permukaan maupun di bawah permukaan air laut (Gambar 1). Hal tersebut didukung oleh persentase akumulasi yang menjawab cukup setuju sampai dengan sangat setuju untuk pesisir pantai dan pemukiman pesisir pantai masing-masing adalah $68 \%$ dan 64\%. Sebagian besar wisatawan berasumsi bahwa sumber terbesar dari kontribusi sampah di pantai ini berasal dari tempat makanan seperti warung kecil dan restaurant dan terbukti $74 \%$ yang cukup setuju sampai dengan sangat setuju. Sumber yang kedua dengan dengan jawaban cukup setuju sampai dengan sangat setuju sebesar 63\% adalah buangan sampah dari pantai seperti sampah dari wisatawan.

Partisipasi masyarakat yang dapat dilakukan dalam aksi mengurangi sampah pesisir di Pantai Pasir Padi berdasarkan hasil kuesioner dari persentase akumulasi pernyataan cukup setuju sampai dengan setuju dari urutan tertinggi ke urutan terendah (Gambar 2), adalah: membuang sampah pada tempat sampah yang sudah ada (78\%), membeli wadah yang dapat digunakan berkali kali dari pada hanya sekali (74\%), aksi bersih pantai (67\%), memamnfaatkan sampah menjadi sesuatu yang berguna $(61 \%)$, dan mengambil sampah yang berisiko terbawa masuk ke laut (55\%). 

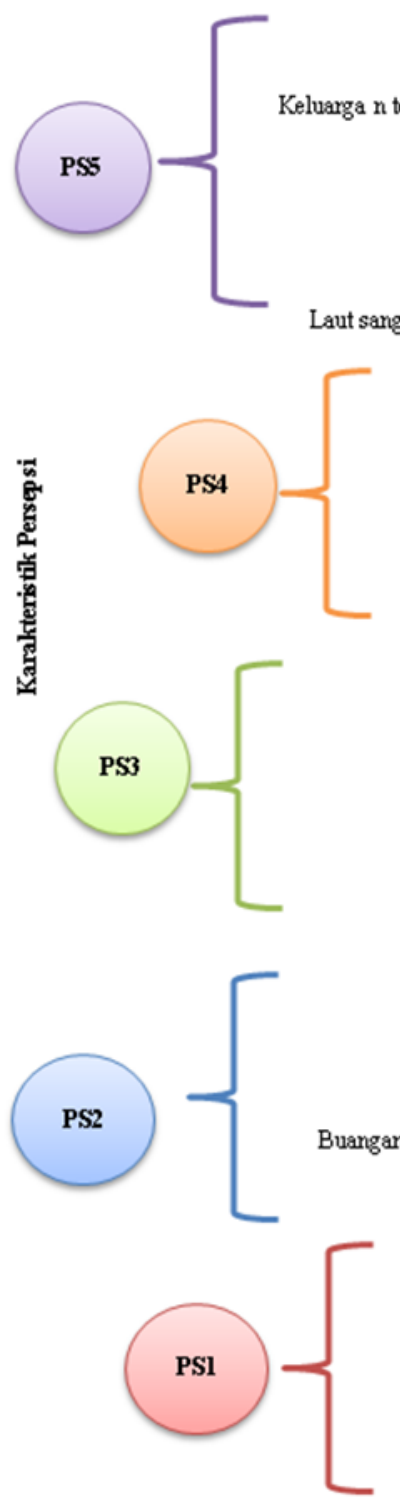

Sampah dari tempat makan (warung kecil dan restaurant) Sampah yang terbawa ke laut karena luapan dari daratan Sampah dari daratan (sungai dan muara) uangan sampah dari laut (aktivitas nelayan, kapel pesisir, aktivitas di.

Buangan sampah dari pantai (contoh: sampah wisatawan) Pemukiman masyarakat pesisir Dibawah permukaan air Pada permukaan laut lepas (jauh dari pantai) Permukaan air laut (yang dapat dilihat dari darat) Pantai 0

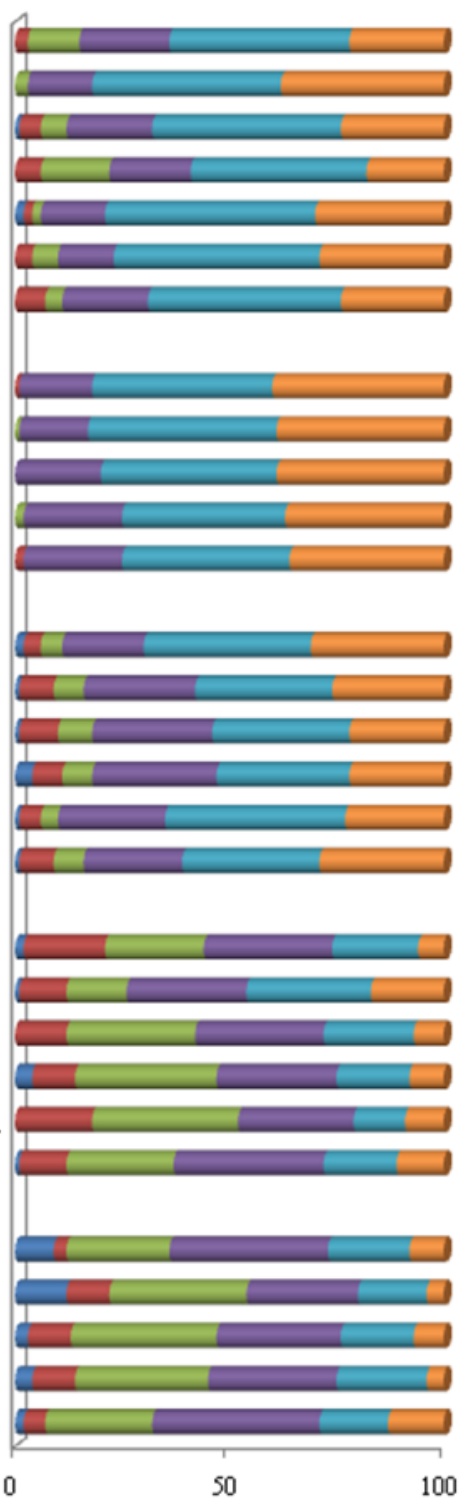

Persentase Persepsi $(\%)$

-Tidak ada Jawaban $\quad$-Sangat tidak setuju $=$ Tidak Setuju $=$ CukupSetuju $=$ Setuju $\|$ Sangat Setuju

Keterangan: PS1 $=$ Lokasi distrbusi sampah pesisir, PS2= Sumber terbesar kontnbusi sampah; PS3 =Faktor penyebab sampah pesisir; PS4= Dampak sampah pesisir; PSS= Pendapat personal tentang sarmpah pesisir

Gambar 1. Persepsi Wisatawan Terkait Sampah di Pantai Pasir Padi, Bangka 


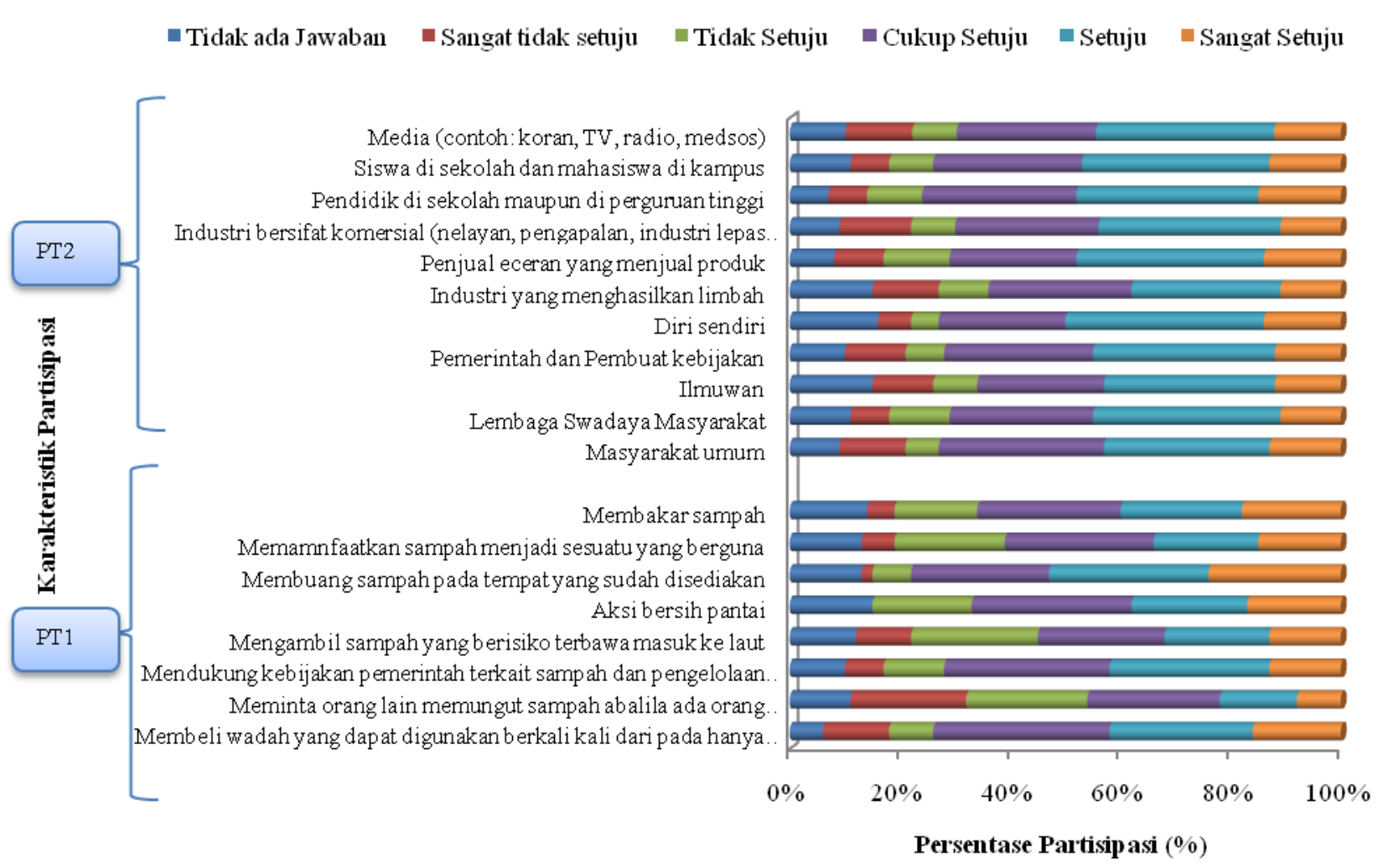

Keterangan : PT1 = Tingkat partisipasi dalam aksi mengurangi sampah di pesisir laut; $\mathrm{PT} 2=$ Yang bertanggungjawab dalam menjaga lingkungan pesisir dari sampah laut

Gambar 2. Partisipasi Wisatawan Terkait Sampah di Pantai Pasir Padi, Bangka

\section{Pembahasan}

Sebagian besar dari wisatawan mengaku bahwa cara mereka membuang sampah, yaitu di tempat sampah, dan yang kedua adalah dengan disimpan di tas dan dibawa pulang. Namun masih ada juga yang mengaku membuang sampah di sembarang tempat dan di jalan. Kondisi seperti ini mengindikasikan bahwa wisatawan sebenarnya sudah memahami konsep/teori bagaimana cara membuang sampah yang baik dan benar, namun belum semua dapat mengaplikasikannya dalam kehidupan sehari-hari. Hal tersebut terbukti masih banyak ditemukan sampah plastik, seperti bungkus makanan dan minuman akibat aktivitas pengunjung dan pedagang di pesisir Pantai Pasir Padi Kota Pangkalpinang Pulau Bangka.

Semua instrumen berupa kuesioner persepsi dan partisipasi wisatawan Pantai Pasir Padi dengan metode korelasi produk momen atau yang dikenal juga dengan korelasi Pearson menunjukkan hasil yang valid, karena terbukti bahwa semua $r$ hitung lebih besar dari $r$ tabel Uji validitas ini dilaksanakan untuk mengetahui instrumen pertanyaan yang digunakan benar-benar handal dan sahih sebagai alat ukur. Begitu juga dengan uji reabilitas terhadap instrumen dengan metode Cronbach's Alpha yang menunjukkan hasil yang reliabel karena nilai Cronbach's Alpha untuk kuesioner persepsi $(0,888)$ maupun partisipasi $(0,987)>0,60$. Hal tersebut mengindikasikan bahwa reliabilitas instrumen kuesioner memiliki reliabilitas yang baik atau kuesioner dapat dipercaya.

Faktor-faktor yang menyebabkan sampah di pesisir pantai berdasarkan kategori cukup setuju-sangat setuju dari persentase terbesar sampai terkecil adalah tidak adanya tempat pembuangan sampah di sekitar pantai (90\%), tidak ada aturan tegas mengenai sampah pesisir (89\%), kebiasaan masyarakat membuang sampah sembarangan (84\%), kebiasaan pelaku industri baik di darat dan di wilayah pesisir $(84 \%)$, berlebihan penggunaan bahan plastik dalam sehari-hari (82\%), dan adanya produk 
sekali pakai (82\%). Tempat sampah sebenarnya sudah disiapkan oleh Pemerintah Kota Pangkalpinang, namun kemungkinan masyarakat merasa masih butuh lebih banyak tempat sampah sehingga dapat mewujudkan kebersihan Pantai Pasir Padi. Hasil kuesioner ini juga dapat memberikan masukan ke pemerintah agar mengeluarkan peraturan daerah yang tegas terkait kebersihan lingkungan, seperti denda yang besar dan hukuman kurungan penjara sehingga dapat memberikan efek jera terhadap pengunjung, pedagang maupun pelaku industri di sekitar pantai. Beberapa di daerah di Indonesia, seperti Jakarta bahkan di luar negeri, seperti: Inggris, Singapura, Hongkong, Jepang dan Jerman sudah memberikan sanksi tegas bagi oknum masyarakat yang membuang sampah sembarangan dengan denda mencapai jutaan rupiah. $^{7}$

Berdasarkan jumlah persentase yang menjawab cukup setuju sampai dengan sangat setuju, didapatkan urutan dampak sampah dari tertitinggi ke rendah, yaitu: kesehatan manusia (100\%), keindahan pantai (99\%), kenyamanan wisatawan pantai (99\%), ekosismtem laut (98\%), dan sektor wisata bahari (98\%). Hasil ini menunjukkan bahwa pemahaman masyarakat terkait dampak dari sampah sudah baik, namun hanya perlu mewujudkannya dalam kehidupan sehari-hari dan bukan hanya sebatas terori. Sampah berupa kaca pecah, logam berkarat dan benda tajam lainnya akan berbahaya bagi kesehatan dan keselamatan pengunjung. ${ }^{8}$ Selain itu, sampah pesisir juga mengakibatkan pemandangan kurang baik sehingga menyebabkan pengunjungan tempat wisata menjadi berkurang dan akibatnya berpengaruh terhadap keuntungan ekonomi. ${ }^{9}$ Kondisi tersebut juga didukung oleh persepsi wisatawan, yaitu: kita harus mengurangi sampah pesisir $(97 \%)$ karena sampah pesisir merupakan masalah penting (94\%) dan ancaman di masa depan (89\%), jumlah sampah pesisir meningkat (88\%), namun beberapa orang tidak peduli dengan sampah pesisir $(85 \%)$.

Wisatawan juga beranggapan yang bertanggung jawab menjaga lingkungan pesisir, yaitu: pendidik di sekolah maupun di perguruan tinggi $(76 \%)$, siswa di sekolah dan mahasiswa di kampus (74\%), masyarakat umum $(73 \%)$, diri sendiri $(73 \%)$, pemerintah dan pembuat kebijakan (72\%), lembaga swadaya masyarakat $(71 \%)$, penjual eceran yang menjual produk $(71 \%)$, industri bersifat komersial (70\%), media (69\%), ilmuwan $(66 \%)$ dan industri yang menghasilkan limbah (64\%). Dari hasil ini dapat dinyatakan bahwa semua kalangan dan lapisan masyarakat mempunyai tanggung jawab penting dalam menjaga kebersihan lingkungan.

\section{Kesimpulan}

Persepsi wisatawan terkait sampah pesisir adalah distribusi sampah paling banyak di pesisir pantai dan pemukiman pesisir pantai, sumber terbesar kontribusi sampah berasal dari tempat makanan, faktor utama penyebab sampah di pesisir pantai adalah tidak adanya tempat pembuangan sampah di sekitar pantai dan tidak ada aturan tegas mengenai sampah pesisir, dampak utama dari sampah adalah kesehatan manusia.

Partisipasi terpenting masyarakat dalam aksi mengurangi sampah pesisir di Pantai Pasir Padi membuang sampah pada tempat sampah yang sudah ada. Semua kalangan dan lapisan masyarakat mempunyai tanggung jawab terhadap kebersihan pantai, seperti: pendidik di sekolah maupun di perguruan tinggi, siswa di sekolah dan mahasiswa di kampus, masyarakat umum, diri sendiri, pemerintah dan pembuat kebijakan, lembaga swadaya masyarakat, penjual eceran yang menjual produk, industri bersifat komersial, media, ilmuwan dan industri yang menghasilkan limbah.

Dalam mewujudkan kebersihan lingkungan pantai semua pihak harus bekerja sama dengan baik dan perlu disiapkan tambahan tempat sampah dan adanya peraturan yang tegas terkait oknum masyarakat yang membuang sampah di pesisir Pantai Pasir Padi Kota Pangkalpinang, Pulau Bangka

\section{Ucapan Terima kasih}

Ucapan terima kasih disampaikan kepada Kemenristek Dikti sebagai pemberi dana penelitian Skema Penelitian Dosen Pemula (PDP) Tahun 2019 No Kontrak 
052/SP2H/LT/DRPM/2019 dan No SK 7/E/KPT/2019. Terima kasih juga kepada Universitas Bangka Belitung yang telah memfasilitasi kegiatan PDP.

\section{Daftar Pustaka}

1. Richardson, R.B. 2010. The Contribution of Tourism to Economic Growth and Food Security.USAID.MALI. pp 1-8.

2. Rosevelt, C, M.L Huertos, C Garza, H.M Nevins. 2013. Marine Debris in Central California: Quantifying Type and Abundance of Beach Litter in Monterey Bay, CA. Marine Poluttion Bulletin.71(12):299-306.

3. [DLH Prov. Kep. Babel] Dinas Lingkungan Hidup Provinsi Kepulauan Bangka Belitung. 2018. Data Timbulan Sampah di Provinsi Kepulauan Bangka Belitung Tahun 2018. Dinas Lingkungan Hidup Provinsi Kepulauan Bangka Belitung.

4. Suryani, A.S. 2016. Persepsi Masyarakat dan Analisis Willingness to Pay terhadap Kebijakan Kantong Plastik Berbayar Studi di Jakarta dan Bandung. Kajian, 21 (4): $359-376$.
5. Vlachogianni, T.2013. Methodology for Monitoring Marine Litter on Beaches Macro-Debris $(>2.5 \mathrm{~cm})$. DeFishGear.MIO- ECSDE.pp 1-16.

6. Nurgiyantoro, B. G., Marzuki. 2000. Statistika Terapan untuk Ilmu-Ilmu Sosial. Yogyakarta: Gadjah Mada University Press.

7. [Perda DKI Jakarta No 3] Peraturan Daerah Daerah Khusus Ibu Kota Jakarata Nomor 3. 2012. Peraturan Daerah Daerah Khusus Ibu Kota Jakarata Nomor 3 tentang Pengelolaan Sampah. Jakarta: Sekretaris Daerah.

8. Tangdesu TRC. 2018. Identifikasi Sampah Laut di Muara Sungai Biringkassi dan Wilayah Pesisir Sekitarnya di Kabupaten Takalar [Skiripsi]. Makasar: Universitas Hasanuddin.

9. Hermawan R. 2017. Analisis Jenis dan Bobot Sampah Laut di Pesisir Barat Pulau Selayar Sulawesi Selatan.

10. Riadi, E. 2016. Statistika Penelitian (Analisis Manual dan IBM SPSS). ISBN: 978-979- 29-5260-5. CV Andi Offset. Yogyakarta. 